To cite: L Botha \& A Kok 'An empirical study of the early cases in the pilot equality courts established in terms of the Promotion of Equality and Prevention of Unfair Discrimination Act 4 of $2000^{\prime}$ (2019) 19 African Human Rights Law Journal 317-336

http://dx.doi.org/10.17159/1996-2096/2019/v19n1a15

\title{
An empirical study of the early cases in the pilot equality courts established in terms of the Promotion of Equality and Prevention of Unfair Discrimination Act 4 of 2000
}

\section{Louis Botha}

Associate, Cliffe Dekker Hofmeyr, Johannesburg, South Africa

Anton Kok

Associate professor, Department of Jurisprudence, Faculty of Law, University of Pretoria, South Africa

https://orcid.org/0000-0002-2746-2286

\section{Summary}

In this article the authors consider the early complaints lodged at the pilot equality courts. Since their inception the equality courts have been underutilised. These early complaints are considered against three themes relating to effective legislation: (1) the legislature must be realistic; (2) different groups of people will be influenced in different ways by a new law; and (3) Parliament should see to it that its laws are popularised. In conclusion the authors offer recommendations on how the utilisation of the equality courts may be improved, among others that equality court personnel should be adequately trained; one forum should be created where any discrimination-related complaint may be lodged; plain language promotional materials should be developed; the parts of the Act that relate to the promotion of equality must come into force; and the workings of the equality courts should be included in the Life Orientation curriculum in schools.

* $\quad$ BCom LLB LLM (Pretoria); louis.botha@cdhlegal.com

** BCom LLB LLM LLD (Pretoria); anton.kok@up.ac.za 
Key words: Promotion of Equality and Prevention of Unfair Discrimination Act; equality courts; effective legislation; societal transformation

\section{Introduction value of research}

South Africa seemingly is the only African country that has put in place an all-encompassing legislative framework combating state and private discrimination based on an open-ended list of prohibited grounds. (An exhaustive scoping exercise of African antidiscrimination legislation falls outside of the domain of the article.) Many African countries' constitutions contain anti-discrimination principles, but these are usually not mirrored in domestic laws. The Regional Office for Southern Africa (ROSA) of the United Nations High Commissioner for Human Rights had previously indicated that it would have worked towards achieving an 'increased number of national anti-discrimination and equality legislation' by $2013 .{ }^{1}$ Some African countries have enacted labour legislation that prohibits discrimination on a number of grounds. ${ }^{2}$ For example, Kenya has passed legislation to prohibit discrimination based on race or ethnicity in employment in its National Cohesion and Integration Act and its Employment Act. $^{3}$ Some African countries have criminalised discrimination, ${ }^{4}$ which South Africa has not (yet) done. As at 31 July 2014, 27 sub-Saharan African countries had adopted HIV-specific legislation - not all these would have been anti-discriminations laws to address the legal issues raised by the HIV and AIDS epidemics. ${ }^{5}$ On the other hand, many African countries have passed deeply problematic laws targeting lesbian, gay, bi-sexual, transgender and intersex (LGBTI) communities. ${ }^{6}$

In this article we focus on one of the South African legislative tools - the Promotion of Equality and Prevention of Unfair Discrimination $\mathrm{Act}^{7}-$ and examine the early cases lodged at the pilot equality courts

1 https://www.ohchr.org/EN/Countries/AfricaRegion/Pages/SouthernAfricaSummary 10.aspx (accessed 25 January 2019).

2 Eg Botswana: https://allafrica.com/view/group/main/main/id/00011743.html (accessed 25 January 2019).

3 www.equalrightstrust.org/ertdocumentbank/Kenya_Part_3_Legal.pdf (accessed 25 January 2019).

4 Eg Mauritania: https://www.cnbcafrica.com/apo/2018/02/01/mauritania-unrights-experts-urge-immediate-reform-of-flawed-antidiscrimination-law/ (accessed 25 January 2019); Tunisia: https://thearabweekly.com/tunisia-become-second-afri can-country-legally-prohibit-racial-discrimination (accessed 25 January 2019); and Rwanda: https://www.newtimes.co.rw/section/read/210899 (accessed 25 January 2019).

5 http://www.unaids.org/en/resources/presscentre/featurestories/2015/february/ 20150211_nigeria_law (accessed 25 January 2019); PM Eba 'HIV-specific legislation in sub-Saharan Africa: A comprehensive human rights analysis' (2015) 15 African Human Rights Law Journal 224.

6 https://www.amnesty.org.uk/lgbti-lgbt-gay-human-rights-law-africa-ugandakenya-nigeria-cameroon (accessed 25 January 2019).

7 Act 4 of 2000 (Equality Act). 
that were established in terms of this Act. The lessons taken from this very modest survey may be of assistance to African legislatures that may be considering similar broad-based anti-discrimination laws.

The ostensible aims of the Equality Act are to facilitate the socioeconomic transformation of South Africa, and to create a caring South African society. ${ }^{8}$ Parliament created equality courts to realise this vision. The Equality Act explicitly targets the effects of past discrimination, which arguably is the reason for the vast disparities in wealth, income and resources in South Africa. The drafters of the Equality Act assumed that the equality courts would effectively address a significant number of incidents of unfair discrimination. While the equality courts have certainly been utilised since their inception in 2003, the number of complaints lodged at these courts fell well short of the target initially forecast. ${ }^{9}$

From the limited information that we were able to obtain, we determined to what extent the Equality Act and the equality courts have contributed to the project of transforming South African society. We conclude by making a number of proposals on how the Equality Act's ability to achieve its transformative aims may be strengthened.

The Act has as one of its goals the establishment of forums where discrimination disputes may be raised and resolved. ${ }^{10} \mathrm{~A}$ number of provisions in section 2 of the Act, which contains the objects of the Act, may be read to create this aim. ${ }^{11}$ Section 2(b)(i) states that the Act aims at giving effect to the letter and spirit of the Constitution, in particular 'the equal enjoyment of all rights and freedoms by every person'. ${ }^{12}$ This subsection anticipates a procedure whereby individual claimants will be able to ensure the enjoyment of their human rights. ${ }^{13}$ Section 2(b)(iv) contains another object of the Act, namely, 'the prevention of unfair discrimination and protection of human dignity as contemplated in sections 9 and 10 of the Constitution'. This subsection, read with sections $2(\mathrm{~d}),^{14} 2(\mathrm{f}),{ }^{15} 4(1)(\mathrm{b}),{ }^{16} 16$ and the regulations to the Act, makes it clear that the Act aims at the creation

8 In earlier research Kok tabulated a number of possible purposes of antidiscrimination legislation. A Kok 'The Promotion of Equality and Prevention of Unfair Discrimination Act 4 of 2000: Proposals for legislative reform' (2008) 24 South African Journal on Human Rights 445451.

9 In the Draft Project Plan drafted by the Chief Director, Transformation and Equity and the Chief Director, Legislation in the Department of Justice and Constitutional Development (copy in possession of authors), it was estimated that in the first year of operation 1,5 million people would use the dispute resolution mechanisms established in terms of the Act.

10 JA Kok 'A socio-legal analysis of the Promotion of Equality and Prevention of Unfair Discrimination Act 4 of 2000' LLD thesis, University of Pretoria, 20089.

11 As above.

12 Our emphasis.

13 Kok (n 10) 9.

14 ' $[$ T] p provide for procedures for the determination of circumstances under which discrimination is unfair'.

15 '[T]o provide remedies for victims of unfair discrimination, hate speech and harassment and persons whose right to equality has been infringed'. 
of inexpensive, accessible, informal dispute resolution mechanisms in the format of equality courts. ${ }^{17}$

To assess the potential impact of these courts, we conducted a telephonic survey of the 47 so-called 'first phase equality courts', all of which are situated at magistrate's courts, as identified by the Department of Justice and Constitutional Development (DOJ) on its website. ${ }^{18}$ This telephonic survey was conducted during the second half of 2009 as part of a post-doctoral research project to identify those equality courts that had received the most complaints with a view to approach these courts, to gain access to the case files and to conduct further empirical research. ${ }^{19}$ The researcher who contacted these pilot courts initially attempted to use a set list of questions on the number and nature of the complaints lodged at these courts: How many equality court cases have been heard/complaints laid since the court's inception; how many cases have been heard/complaints have been laid in each year since inception; what were these cases about, i.e. did they relate to discrimination/hate speech/harassment and on which prohibited ground(s); has the court handed down any judgments? However, as most of these pilot courts could not offer much information, he then proceeded to base his questions on whatever information these courts could offer. The authors did not regard the nature of the information sought as research on human subjects and therefore did not apply for ethical clearance at the Faculty of Law's research ethics committee. All of the information sought would have been a matter of public record available at each of the courts. Instead of incurring substantial costs to travel to each of the courts to draw the equality court files and tabulate the available information, the researcher telephoned each of the courts to obtain whatever information was available. In many instances the researcher could not speak to the equality court clerk and had to make do with whoever was available to speak to. In some instances no trained equality court clerk was available. Some of the staff members contacted offered off-the-cuff anecdotal views on the low number of complaints lodged at the equality courts. We included these views in this article to enrich the analysis of the data obtained but anonymised their responses. No systematic survey of clerks' views was undertaken or intended. Where we do mention some of these views, it is to offer an example or to elucidate a point we make in the article. We tabulate below the findings of this telephonic survey and compare it to (i) the

16 'In the adjudication of any proceedings which are instituted in terms of or under this Act, the following principles should apply: ... (b) access to justice to all persons in relevant judicial and other dispute resolution forums.'

17 Kok (n 10) 10.

18 http://www.doj.gov.za/EQCact/eqc_eqc\%20structures.htm (accessed 18 December 2009). See also http://www.pmg.org.za/docs/2003/appendices/030404dept justice.htm (accessed 10 September 2014) where reference is made to the establishment of 47 first-phase equality courts.

19 We will refer to this survey as the '2009 survey'. At the time of writing the authors were in possession of 994 equality court case files. 
findings of a survey conducted by Kok in 2005 as part of his doctoral thesis; ${ }^{20}$ and (ii) a survey conducted by the South African Human Rights Commission (SAHRC) in 2005 and 2006. ${ }^{21}$

The findings of these surveys, along with feedback provided by court officials during the 2005 and 2009 surveys, are then assessed with reference to three of the four criteria of effective legislation as proposed by Kok, ${ }^{22}$ namely, that (i) the legislature must be realistic; ${ }^{23}$ (ii) different groups of people will be influenced in different ways by a new law; ${ }^{24}$ and (iii) to have any hope of legislating effective laws, Parliament should see to it that its laws are popularised. ${ }^{25}$ The fourth criterion, that 'the values (implicitly) underpinning a given new law should not run too far ahead of society's contemporaneous mores', 26 could not be accurately assessed due to the methodology used for gathering the information set out below.

20 Kok (n 10) 623-642 ('2005 survey'). The 2005 survey focused on the 60 pilot courts as listed in a booklet entitled Equality for all published under the auspices of the Department of Justice. These courts differ from the pilot courts listed on the Department of Justice's website when the 2009 survey was conducted.

21 See Kok (n 10) 623-642 ('SAHRC survey').

22 A Kok 'The potential effectiveness of the Promotion of Equality and Prevention of Unfair Discrimination Act 4 of 2000' (2008) 33 Journal for Juridical Science 42.

23 The goal of the law maker must be realisable through law; the required change must be able to be implemented and to be strongly enforced; rules will be enforced that are highly visible, cost little and do not affect competition; enforcement agents must be committed to the behaviour required by the law, even if not to the values implicit in it; a law that does not establish a clear standard or that is ambiguous or too flexible will facilitate avoidance; the changeinducing law must provide for effective remedies; to have any hope of effective enforcement, the state driving social change must be relatively powerful, and must have significant technological surveillance facilities available; the enforcement mechanism should consist of specialised bodies and the presiding officers of these enforcement mechanisms must receive training to acquire expertise.

24 Large organisations with specialised personnel that are well-equipped to interpret rules will probably be committed to implementing new laws, but small businesses, individual home owners, small landlords and individuals will probably not have sufficient knowledge, and implementation on this level will be very difficult to achieve; laws put in place to assist or protect the economically weak will have limited impact; laws such as these should be complemented by active and effective non-governmental support.

25 The use of the law will increase if the educational system is used in a well-directed way as a 'nationally inclusive socialising agent'; the required change must be communicated to the large majority of the population; laws that include incentives to encourage lawyers to use the new law and to inform clients of the existence of the new law, are more likely to be effective; the state driving social change must be able to rely on vast mass media communication.

26 The purpose behind the legislation must at least to a degree be compatible with existing values; laws set up in opposition to powerful economic values and interests may also (eventually) fail; laws that facilitate action that people want to take or that encourage voluntary change is likely to be more effective than compulsory change; models or reference groups must be used for compliance; laws are more effective when introduced to change emotionally neutral and instrumental areas of human activity; law must make conscious use of the element of time in introducing a new pattern of behaviour. 
To date very little empirical research has been undertaken to assess the (potential) effectiveness of the equality courts. Kruger conducted a study in 2007 and 2008 regarding the number of complaints, relating to racism, that had been received by the equality courts situated in Pretoria, Johannesburg, Durban and Cape Town in order to determine how the Act was implemented, and found that relatively few complaints had been made to the equality courts since their inception and that this limited the opportunities of these courts to establish themselves as meaningful catalysts of social change. ${ }^{27}$ The Refugee Rights Unit at the University of Cape Town, in approaching the equality court on two occasions on behalf of victims of xenophobic violence, also remarked that based on their experience, in practice it seemed that these courts were being underutilised. ${ }^{28}$ This article makes a modest contribution to the empirical research that has been done regarding the (potential) effectiveness of the equality courts and should be used as a basis for further and more current empirical studies to examine whether any progress has been made in addressing the problems hampering the potential effectiveness of the Act that were identified here.

\section{Provincial breakdown: Findings from the 2005, 2009 and SAHRC surveys}

In this part we set out the findings of the 2009 survey along with the findings from the 2005 and SAHRC surveys for courts in each province. Where no or limited information was forthcoming or if a court forming part of the 2009 survey did not form part of the other two surveys, this is also indicated. The phrase 'not yet established' indicates that the equality court in question had not yet been established when a particular survey was conducted.

27 R Kruger R 'Small steps to equal dignity: The work of the South African equality courts' (2011) 7 Equal Rights Review 2739.

28 J de Jager 'Litigating the rights of refugees in the equality courts' Working Paper Series (Paper 3 of 2011) University of Cape Town, Refugee Rights Unit 5. 
Table 1: Summary of the findings from the 2005, 2009 and SAHRC surveys

\begin{tabular}{|c|c|c|c|c|}
\hline \multirow[t]{2}{*}{ Province } & \multirow[t]{2}{*}{ Court } & \multicolumn{3}{|c|}{ Number of complaints received } \\
\hline & & 2009 survey & 2005 survey & $\begin{array}{l}\text { SAHRC } \\
\text { survey }\end{array}$ \\
\hline \multirow[t]{6}{*}{$\begin{array}{l}\text { KwaZulu- } \\
\text { Natal }\end{array}$} & Pietermaritzburg & $\begin{array}{l}27(6 \text { in } \\
2009)\end{array}$ & 1 & 5 \\
\hline & Verulam & $4^{\mathrm{a}}$ & 4 & 9 \\
\hline & Ngutu & 0 & 0 & 0 \\
\hline & Ladysmith & 1 & 1 & 0 \\
\hline & Port Shepstone & 1 (in 2009) & $\begin{array}{l}\text { Not part of } \\
\text { survey }\end{array}$ & $\begin{array}{l}\text { Not part of } \\
\text { survey }\end{array}$ \\
\hline & Durban & \begin{tabular}{|l|} 
No \\
information \\
forthcoming
\end{tabular} & 150 & \begin{tabular}{|l|} 
No \\
information \\
forthcoming
\end{tabular} \\
\hline \multirow{4}{*}{$\begin{array}{l}\text { Western } \\
\text { Cape }\end{array}$} & Atlantis & 2 & 2 & 2 \\
\hline & Blue Downs & 1 & $\begin{array}{l}\text { Not listed as } \\
\text { equality court }\end{array}$ & 1 \\
\hline & George & 1 & 1 & 1 \\
\hline & Worcester & $\begin{array}{l}2 \text { (both in } \\
2009 \text { ) }\end{array}$ & 2 & 0 \\
\hline \multirow{6}{*}{$\begin{array}{l}\text { Northern } \\
\text { Cape }\end{array}$} & Kenhardt & 0 & 1 & 0 \\
\hline & De Aar & 0 & 1 & 2 \\
\hline & Carnavon & 0 & $\begin{array}{l}\text { Not part of } \\
\text { survey }\end{array}$ & $\begin{array}{l}\text { Not part of } \\
\text { survey }\end{array}$ \\
\hline & Postmasburg & 0 & $\begin{array}{l}\text { Not part of } \\
\text { survey }\end{array}$ & 0 \\
\hline & Upington & 0 in $2009^{c}$ & $\begin{array}{l}\text { Number does } \\
\text { not exist }\end{array}$ & 17 \\
\hline & Calvinia & 0 & $\begin{array}{l}\text { Not part of } \\
\text { survey }\end{array}$ & 0 \\
\hline \multirow[t]{4}{*}{ Limpopo } & Polokwane & $3(2$ in 2009$)$ & 1 & \begin{tabular}{|l} 
No \\
information \\
forthcoming
\end{tabular} \\
\hline & Makhado & 1 (in 2009) & 1 & 1 \\
\hline & Bela-Bela & 3 & 0 & \begin{tabular}{|l|} 
No \\
information \\
forthcoming
\end{tabular} \\
\hline & Mapulaneng & $\begin{array}{l}\text { No equality } \\
\text { court }\end{array}$ & 0 & $\begin{array}{l}\text { No } \\
\text { information } \\
\text { forthcoming }\end{array}$ \\
\hline
\end{tabular}




\begin{tabular}{|c|c|c|c|c|}
\hline & Mokerong & $\begin{array}{l}\text { No equality } \\
\text { court }\end{array}$ & 9 & $\begin{array}{l}\text { No } \\
\text { information } \\
\text { forthcoming }\end{array}$ \\
\hline & Ritavi & 3 (in 2009) & 0 & 3 \\
\hline \multirow[t]{4}{*}{ Free State } & Bethlehem & 4 & 1 & \begin{tabular}{|l|} 
No \\
information \\
in survey
\end{tabular} \\
\hline & Odendaalsrus & 2 & 0 & $\begin{array}{l}\text { Not part of } \\
\text { survey }\end{array}$ \\
\hline & Kroonstad & 0 & 0 & $\begin{array}{l}\text { No equality } \\
\text { court }\end{array}$ \\
\hline & Jagersfontein & $\begin{array}{l}\text { No equality } \\
\text { court }\end{array}$ & 0 & \begin{tabular}{|l|}
$\begin{array}{l}\text { Not part of } \\
\text { survey }\end{array}$ \\
\end{tabular} \\
\hline \multirow[t]{3}{*}{ North West } & Potchefstroom & $\begin{array}{l}31(14 \text { in } \\
2009)\end{array}$ & 7 & 37 \\
\hline & Bafokeng & 1 & $\begin{array}{l}\text { No } \\
\text { information } \\
\text { forthcoming }\end{array}$ & $3^{d}$ \\
\hline & Vryburg & 0 & 2 & 0 \\
\hline \multirow[t]{6}{*}{\begin{tabular}{|l} 
Eastern \\
Cape
\end{tabular}} & Port Elizabeth & \begin{tabular}{|l} 
No \\
information \\
forthcoming
\end{tabular} & $\begin{array}{l}\text { No } \\
\text { information } \\
\text { forthcoming }\end{array}$ & $\begin{array}{l}\begin{array}{l}\text { Not part of } \\
\text { survey }\end{array} \\
\end{array}$ \\
\hline & Somerset West $\mathrm{t}^{\mathrm{e}}$ & \begin{tabular}{|l|} 
No \\
information \\
forthcoming
\end{tabular} & $\begin{array}{l}\text { Not part of } \\
\text { survey }\end{array}$ & $\begin{array}{l}\text { Not part of } \\
\text { survey }\end{array}$ \\
\hline & Zwelitsha & 0 & 0 & \begin{tabular}{|l|} 
Not yet \\
established
\end{tabular} \\
\hline & Aliwal North & 1 & $\begin{array}{l}\text { No } \\
\text { information } \\
\text { forthcoming }\end{array}$ & $\begin{array}{l}\text { Not part of } \\
\text { survey }\end{array}$ \\
\hline & \begin{tabular}{|l|} 
Umzimkhulu \\
\end{tabular} & 0 & \begin{tabular}{|l} 
No \\
information \\
forthcoming
\end{tabular} & $\begin{array}{l}\begin{array}{l}\text { Not part of } \\
\text { survey }\end{array} \\
\end{array}$ \\
\hline & Elliotdale & $\begin{array}{l}\text { No equality } \\
\text { court }\end{array}$ & 0 & $\begin{array}{l}\text { Not part of } \\
\text { survey }\end{array}$ \\
\hline \multirow[t]{5}{*}{ Gauteng } & Wonderboom & $\begin{array}{l}\text { No equality } \\
\text { court }\end{array}$ & 0 & 0 \\
\hline & Kempton Park & $\begin{array}{l}\text { No equality } \\
\text { court }\end{array}$ & 2 & 6 \\
\hline & Johannesburg & $\begin{array}{l}61(37 \text { in } \\
2009)^{f}\end{array}$ & $\begin{array}{l}\text { No } \\
\text { information } \\
\text { forthcoming }\end{array}$ & 54 \\
\hline & Germiston & 14 & $\begin{array}{l}\text { No } \\
\text { information } \\
\text { forthcoming }\end{array}$ & 3 \\
\hline & Randburg & 8 (all in 2009) & 0 & $\begin{array}{l}\text { Not part of } \\
\text { survey }\end{array}$ \\
\hline
\end{tabular}




\begin{tabular}{|l|l|l|l|l|}
\hline & Pretoria & 45 in $2009^{\mathrm{h}}$ & 8 & $77^{\mathrm{i}}$ \\
\hline $\begin{array}{l}\text { Mpumalan } \\
\text { ga }\end{array}$ & Nkomazi & 0 & $\begin{array}{l}\text { Not part of } \\
\text { survey }\end{array}$ & $\begin{array}{l}\text { Not part of } \\
\text { survey }\end{array}$ \\
\hline & Eerstehoek & $\begin{array}{l}19(13 \mathrm{in} \\
2009)\end{array}$ & 0 & $\begin{array}{l}\text { Not part of } \\
\text { survey }\end{array}$ \\
\hline & Middelburg & $\begin{array}{l}\text { No equality } \\
\text { court }\end{array}$ & 0 & 1 \\
\hline & Kwa-Mhlanga & 0 & 2 & 8 \\
\hline & Secunda & $\begin{array}{l}\text { No equality } \\
\text { court }\end{array}$ & $\begin{array}{l}\text { Not part of } \\
\text { survey }\end{array}$ & $\begin{array}{l}\text { Not part of } \\
\text { survey }\end{array}$ \\
\hline Total & 276 & $\begin{array}{l}\text { Not part of } \\
\text { survey }\end{array}$ \\
\hline
\end{tabular}

a. We were told that four judgments had been handed down but were not given the total number of complaints received.

b. We were later told that 64 complaints were received in 2009 .

c. No information was provided for previous years.

d. Survey indicates that the clerk had a new register for 2006 and that there were no records for 2004 and 2005.

e. Somerset West is actually situated in the Western Cape, but was listed as falling in the Eastern Cape. This is most probably a mistake that was made in the Equality for all booklet. Somerset East was one of the courts that formed part of the 2005 and SAHRC surveys.

f. We were only given information from complaints received in 2008 and 2009 .

g. The relevant member of staff refused to provide Kok's research assistant with any information and argued that such a request should be channelled via the Magistrate's Commission.

h. No information was provided to us for previous years.

i. Referred to as 'Pretoria Central' court in this survey.

As far as reporting by the Department of Justice is concerned, the number of equality court cases for April 2008 to March 2009 (financial year) was 447, according to the Department's Annual Report. ${ }^{29}$ A breakdown per province, which is not in the Annual Report, reveals the following: ${ }^{30}$

\begin{tabular}{|l|l|l|l|l|l|}
\hline Provinces & $\begin{array}{l}\mathbf{1}^{\text {st }} \\
\text { Quarter }\end{array}$ & $\begin{array}{l}\mathbf{2}^{\text {nd }} \\
\text { Quarter }\end{array}$ & $\begin{array}{l}3^{\text {rd }} \\
\text { Quarter }\end{array}$ & $\begin{array}{l}\mathbf{4}^{\text {th }} \\
\text { Quarter }\end{array}$ & TOTAL \\
\hline 1 Eastern Cape & 08 & 01 & 01 & 05 & 15 \\
\hline
\end{tabular}

29 This number is for all the equality courts countrywide and not only those that formed part of our survey.

30 This table was provided to us by Ms Lynette Bios, who was a Senior State Law Advisor in the Department of Justice when she provided it to us in December 2009. 


\begin{tabular}{|l|l|l|l|l|l|}
\hline 2 Free State & 00 & 02 & 01 & 00 & 03 \\
\hline 3 Gauteng & 03 & 19 & 10 & 29 & 61 \\
\hline 4 Kwazulu-Natal & 35 & 26 & 11 & 21 & 93 \\
\hline 5 Limpopo & 01 & 02 & 00 & 00 & 03 \\
\hline 6 Mpumalanga & 46 & 48 & 29 & 68 & 191 \\
\hline 7 Northern Cape & 15 & 02 & 01 & 00 & 18 \\
\hline 8 North West & 06 & 05 & 05 & 07 & 23 \\
\hline 9 Western Cape & 20 & 05 & 08 & 07 & 40 \\
\hline
\end{tabular}

As not all the courts in the 2009, 2005 and SAHRC surveys could provide us with accurate information, it is difficult to say how many complaints had been received by each court. However, it could probably be safely stated that based on the information from these surveys and from the DOJ's Annual Report, the courts were underutilised and, with the benefit of hindsight, the drafters of the Act, who envisaged that 1,5 million people would use the equality courts in the first year of the Act's operation, ${ }^{31}$ were unrealistic.

\section{Analysis: Why were the equality courts not being utilised?}

In this part of the article we identify possible reasons for the underutilisation of the equality courts based on relevant criteria for effective legislation. The information in this section, unless otherwise indicated, was obtained in the course of conducting the 2009 survey.

\subsection{The legislature must be realistic}

It is crucial that equality clerks, equality magistrates and court personnel in general are committed to assisting complainants when they approach these officials. At two courts in Gauteng we found that the equality court clerks either went to great trouble to assist complainants to complete the necessary complaint forms or to make a point of telling people about the equality court when they came to the magistrate's court where the equality court is situated. In other instances the court personnel did not adopt this attitude. In one instance, a clerk told us that limited marketing had been done for fear of equality courts being 'abused', and at another court the supervisory official we spoke to indicated that the Act had not had the desired effect as equality clerks were not very willing to go out into the community and promote the Act. Where such an attitude of unwillingness prevails, the Act will not have its intended effect.

31 This view was stated on page 6 of the Draft Project Plan drafted by the Chief Director, Transformation and Equity and the Chief Director, Legislation in the Department of Justice and Constitutional Development; see Kok (n 10) 99-100. 
In theory specialised enforcement bodies - equality courts - had been set up across the country, but it is questionable whether presiding officers had received adequate and sustained training. ${ }^{32}$ Presiding officers ${ }^{33}$ and equality clerks ${ }^{34}$ are required to complete a training course in terms of the Act before they can be appointed to act in these capacities. A case heard by the Bethlehem equality court, which was incorrectly referred to the civil court due to the magistrate indicating that the court could not order the quantum of damages sought by the complainant, is a possible example of inadequate training as section $21(2)(d)$ of the Act gives any equality court the power to award damages or compensation in favour of the complainant, and as the Act has done away with the ordinary monetary limit on magistrate's courts. Even if the amount requested exceeded the monetary jurisdiction of a magistrate's court, a magistrate's court sitting as an equality court can still grant such an amount of damages in favour of the complainant, provided that such an order must be confirmed by a High Court that has jurisdiction over the matter, in terms of section 19(3)(a) of the Act.

Although most of the courts had trained personnel, it is problematic that many of the courts contacted during the 2009 survey did not even have an equality court or a person who was trained to perform the functions of an equality clerk. The magistrate's courts in Kempton Park, ${ }^{35}$ Evander, ${ }^{36}$ Mokerong, Mapulaneng, Jagersfontein, ${ }^{37}$ Secunda ${ }^{38^{\prime}}$ and Wonderboom had neither an equality clerk nor an equality court when we contacted them. The equality courts in Carnavon and Elliotdale did not have equality clerks, as they had been transferred to other courts in 2008. There was also no equality clerk in Germiston ${ }^{39}$ and Polokwane ${ }^{40}$ when we contacted the courts, meaning that 11 of the 47 first-phase courts that we contacted (almost 25 per cent) did not have a trained equality clerk who could deal with complaints if any were received.

Fortunately, in terms of section 17(1)(b) of the Act, the presiding officer concerned may appoint any competent officer in the DOJ to act as a clerk until a clerk has been designated or appointed in terms of section 17(1)(a) of the Act. However, this is not an ideal situation, if

$32 \operatorname{Kok}(\mathrm{n} 10) 58$.

33 Sec 16(2) of the Act.

34 Sec 17(2) of the Act.

35 We were told that there were offices available that would be utilised for the equality court and the family court.

36 We were told that the equality court would be set up in future. A person was sent to attend the training course for equality clerks in May 2009.

37 The court falls within the district of the Fauresmith magistrate's court, from where the equality court would operate.

38 We were told that although an equality court would be set up there, this never materialised.

39 We were told that the position was vacant.

40 Other clerks that had not completed the training course were being utilised at the equality court. 
one considers the extensive and specialised role played by an equality clerk in assisting complainants to complete the complaint forms. This much is evident from paragraph 5 of the Act's regulations, which sets out the additional functions of the clerk, and particularly subparagraph 5(e), which states that the clerk must assist illiterate or disabled persons in completing the requisite documents, and subparagraph 5(f)(iv), which states that the clerk must assist an unrepresented person by, inter alia, reading or explaining any documentation to him or her, which could include the provisions of the Act.

From an accessibility viewpoint, it would have been better if a 'one stop shop' were created for all discrimination complaints as opposed to the current situation where workplace-related incidents are usually heard in the Labour Court in terms of the Employment Equity Act, while all other complaints are heard in the equality courts. ${ }^{41}$ For the 2009 survey an Area Court Manager informed us that one of the reasons for the lack of complaints received by that equality court was that potential claimants' grievances often arose in a workplace context, meaning that it had to be dealt with by the Labour Court as opposed to the equality court. At another equality court, the clerk also opined that many people who approached the court confused labour law matters with equality court matters.

\subsection{Different groups of people will be influenced in different ways by a new law}

In this respect, it is important to note that people's interpretation of what happens to them depends on their social surroundings and not on the law. ${ }^{42}$ For instance, the Court Manager at one of the equality courts situated in a rural area believed that although a lot of discrimination takes place amongst the community, people rather reverted to traditional courts than the equality courts, because of their strong cultural roots. During the 2009 survey we found that a number of equality courts had been underutilised or not at all although people in these communities had been made aware of the equality courts.

At one of the equality courts, the presiding magistrate we spoke to stated that issues of inequality were not a problem as only black people lived in this township community. Interestingly, he mentioned that people had 'come in droves' to bring complaints in terms of the Domestic Violence Act. The magistrate's statement regarding issues of inequality is problematic, as it presumes that issues of inequality only arise where people live in a community comprised of people from different racial and cultural backgrounds. This goes against the spirit

$41 \quad$ Kok (n 10) 58.

42 J Griffiths 'The social working of anti-discrimination law' in T Loenen \& PR Rodrigues Non-discrimination law: Comparative perspectives (1999) 315-318, as cited in Kok (n 10) 52. 
of the Act, which lists 17 prohibited grounds 43 on which discrimination, hate speech and harassment may not take place. A number of these grounds are not related to race or culture, such as gender, disability ${ }^{44}$ and sexual orientation. HIV and AIDS, although not listed as a prohibited ground, is also a ground on which discrimination can take place in such communities, ${ }^{45}$ especially considering the high estimated number of people in South Africa who are HIV positive. ${ }^{46}$ The magistrate's opinion is a good example of how people are not aware of the ambit and purpose of the Act and of the range of complaints that may be lodged with an equality court. At one of the rural equality courts, the Area Court Manager suggested that there might not be a need for an equality court in smaller areas. In another small-town equality court, the equality clerk indicated that people who were aware of the Act seemed to misunderstand its purpose and approached the equality court for the 'smallest things'. The clerk did not explain exactly what she meant by this, but presumably these were complaints that could not be heard by the equality court. Arguably 'the smallest things' are precisely the kind of matters that should be brought to equality courts so that courts can assist in creating a more caring South African society.

The equality courts in Worcester and Kenhardt had been approached with enquiries relating to the issue of unfair dismissal, which had to be dealt with by the Labour Court. ${ }^{47}$ In Kenhardt, for example, potential complainants often confused labour-related issues

43 See the definition of prohibited grounds in sec 1(a) of the Act.

$44 \mathrm{Sec} 2(\mathrm{c})$ of the Act states that the Act is in particular concerned with eradicating hate speech, discrimination and harassment on the grounds of gender, disability and race.

45 HIV/AIDS can be a prohibited ground based on para (b) of the definition of prohibited grounds, which states that a ground will be a 'prohibited ground' if it (i) causes or perpetuates systemic disadvantage; (ii) undermines human dignity; (iii) adversely affects the equal enjoyment of a person's rights and freedoms in a serious manner that is comparable to discrimination on a ground in para (a) of the definition of prohibited grounds. Furthermore, sec 34(1) of the Act mandates the Minister of Justice to consider including HIV/AIDS status as a prohibited ground in the definition in para (a) and that the Equality Review Committee makes a recommendation to the Minister in this regard, within one year of the commencement of the Act. Thus far nothing has come of this.

46 According to the World Health Organisation, South Africa has the biggest HIV epidemic in the world and it is estimated that approximately 5,6 million people were HIV positive in 2009; http://www.who.int/hiv/pub/progress_report2011/ regional_facts/en/index.html (accessed 28 November 2012).

$47 \mathrm{Sec} 157(1)$ of the Labour Relations Act states that the Labour Court has the exclusive jurisidiction to hear matters pertaining to the unfair dismissal of a person. Furthermore, sec 5(3) of the Act states that the Act does not apply to any person to whom and to the extent to which the Employment Equity Act 55 of 1998 applies. This provision can exclude the Equality Court's jurisdiction to hear a matter regarding unfair discrimination or harassment in the workplace, as secs 6(1) and 6(3) of the Employment Equity Act prohibit unfair discrimination and harassment respectively. See eg the judgment in Strydom v Chiloane 2008 (2) SA 247 (T) and Kok's criticism of the case. A Kok 'Which is the appropriate forum when hate speech occurs in the workplace: The Equality Court or Labour Court? Strydom v Chiloane 2008 (2) SA 247 (T)' 2009 (24) SA Public Law 651. 
with matters of equality, with the equality court being approached by farm workers who had been evicted from farms. Also, in Atlantis two cases were dismissed as they clearly fell outside the court's jurisdiction. At an equality court in a larger town, the clerk commented that mostly 'well-educated' people had approached the court. In similar vein, an office manager at a small-town equality court stated that the reason for no complaints being brought was, inter alia, that most complainants were illiterate. The Acting Court Manager at one of the courts stated that one of the reasons for the lack of complaints was that people rather brought claims that involved money. This could be seen as an unintended consequence of the Act's aim of transforming South African society through a 'changing of hearts', 48 as infringements of equality in terms of the Act do not involve money per se, although section 21(2)(d) of the Act lists the payment of damages as one of the remedies that an equality court can order. The office manager at an equality court situated in a remote and poor area suggested that approaching the equality court to address incidents of discrimination, harassment or hate speech was not a priority for residents in the area as they had other more pressing concerns.

In some instances the 2005 survey also showed how a lack of knowledge led to no complaints being brought. This occurred at the Mapulaneng equality court where the clerk stated that no complaints had been reported, inter alia, as people thought that you could not approach the courts for something 'as simple as' discrimination or hate speech despite the fact that discrimination was prevalent in the area due to many different ethnic groups living there, including foreigners. ${ }^{49}$ The Evander equality clerk also stated that no complaints had been received as discrimination did not occur on a wide scale or that it was of a minor nature when it did take place. ${ }^{50}$ The clerk at the Ritavi equality court reported that the complaints received had not been followed up due to residents not thinking that hate speech spoken by their superiors qualified as an offence and as confusion existed between the Act and the Domestic Violence Act. ${ }^{51}$ What is clear from all of this is that, based on the information obtained from equality court clerks, in general the public did not seem to understand the purpose of the Act and under which circumstances the equality court could be approached.

\subsection{Parliament should see to it that its laws are popularised ${ }^{52}$}

Kok previously argued that the poor implementation of the training programme for judicial officers gave an indication that the

48 Kok (n 10) 44.

49 Kok 624.

50 Kok 627.

51 Kok 624.

52 What is implied here is that Parliament should play an appropriate oversight role in ensuring that the Department of Justice has proper and sustained popularisation programmes in place. 
Department of Justice was not capacitated to play a meaningful role in enforcing compliance with the Act. ${ }^{53} \mathrm{He}$ also noted the serious discrepancies that existed between the findings of the 2005 survey and the SAHRC survey, which were conducted at more or less the same time. ${ }^{54}$ Taking into account courts in the table above from which information was forthcoming, a comparison of the statistics from the 2005 and SAHRC surveys reveals discrepancies at the following equality courts: Pietermaritzburg, Worcester, De Aar, Upington, Ritavi, Makhado, Polokwane, Bethlehem, Potchefstroom, Vryburg, Kempton Park, Germiston, Pretoria, Evander and Middelburg. This means that at almost a third of the courts, different information was provided to Kok during the 2005 survey and to the SAHRC when conducting its survey, which could indicate that poor record keeping took place.

Similar discrepancies arose in the 2009 survey: For instance, at the Ladysmith equality court both the 2009 and 2005 surveys found that only one case had been reported, but where the 2009 survey indicated that the matter had been settled, the 2005 survey found that the matter had been referred to an alternative forum. The Wonderboom equality court reported during the 2009 survey that no equality court had been set up nor an equality clerk appointed since the court's inception in 2004, although the equality clerk reported in the 2005 survey that no complaints had been received. The George equality court indicated during the 2005 and 2009 surveys that only one case had been received but indicated different outcomes for this case, assuming that the correct information was provided to us during both surveys.

According to Motsaathebe and Mnjama, good record keeping is fundamental to the efficient operation of the legal system of a country the administration of justice and the protection of citizens' rights. ${ }^{55}$ Poor record keeping could therefore be an indication that the equality courts were not being run by court personnel in such a way as to advance the aims of the Act.

The 2009 survey also showed that 11 courts were either without an equality clerk or had no equality court whatsoever. This is a further indication of the problem of incapacity that hampered the DOJ at the time. Although no information was forthcoming from the Durban equality court during the 2009 survey, the court was extremely helpful when we approached them again during 2011 and subsequently in conducting empirical research. The 2005 survey showed that this court had dealt with approximately 150 cases from the period July 2004 to March 2006 of which 81 cases had been finalised, with 27 of these finalised cases being decided in favour of

\footnotetext{
53 Kok (n 10) 58.

54 Kok 57.

55 L Motsaathebe L \& N Mnjama 'Managing court records: A survey of recordkeeping practices in selected countries' (2009) 7 Mousaion 132133.
} 
the respondent. ${ }^{56}$ This shows that there are certain courts that are well capacitated to receive and deal with complaints in a manner that promotes the objects of the Act.

Earlier research indicated that many potential users of the equality courts (individual victims of discrimination) were not aware of the courts. ${ }^{57}$ Excluding the courts where incorrect numbers were provided by the DOJ and where no information was forthcoming, 20 of the 47 courts had not received any complaints whatsoever according to the 2009 survey. This means that almost half of the courts that were contacted had not received any complaints. At a number of equality courts, the court official we spoke to expressed the belief that people in the area were not aware of the Act and of the equality court due to insufficient marketing of the equality court. Some of these clerks thought that better marketing or outreach programmes might lead to more complaints being received by this court.

In some cases, public awareness campaigns did take place, but did not have the desired effect. For example, at a rural equality court the 2005 survey found that the lack of complaints received was due to a lack of awareness among the community, ${ }^{58}$ but subsequent efforts to promote the equality court by advertising it in the community and by making pamphlets available in Zulu, ${ }^{59}$ did not have the desired effect as no complaints had been received according to the 2009 survey. The clerk at the Wonderboom equality court indicated during the 2005 survey that no complaints had been received despite advertisements and media coverage of the court. ${ }^{60}$

56 Kok (n 10) 639-641.

57 Kok 69.

58 Kok 638.

59 Although we found in the 2009 survey that it was the exception rather than the rule for pamphlets or other information about the court to be made available in one of the official languages other than English, this situation must change in light of the North Gauteng High Court's order handed down in 2012, that the Act and all related paperwork has to be translated into all 11 official languages. The Court gave this order after Mr Cerneels Lourens had taken the Minister of Justice, Mr Jeff Radebe, to court for failing to make the Equality Act and its prescribed forms available in all 11 official languages at all courts. Mr Lourens contended that this failure was in violation of sec 31(2)(b) of the Act, which states that the Minister of Justice must make the Act available in all official languages within a period of two years after the commencement of the Act. P de Bruin 'Taalstryder hof toe oor wet se vorms' Beeld http://www.beeld.com/Suid-Afrika/Nuus/Taalstryder-hof-toe-oorwet-se-vorms-20120409 (accessed 21 November 2012). In court papers, the Minister conceded that at most courts the forms were available only in English and Zulu. He agreed to have the Act and all related paperwork translated into all 11 languages and this settlement was made an order of court. $P$ de Bruin 'Oorwinning vir blinde taalvegter' Beeld http://www.beeld.com/Suid-Afrika/Nuus/ Oorwinning-vir-blinde-taalvegter-20120423 (accessed 21 November 2012). 
Public awareness must arguably be maintained over the long term. ${ }^{61}$ According to the DOJ's Annual Report ${ }^{62}$ for the 2008/2009 financial year, more than 300 outreach workshops had been conducted in promoting the Act, the Promotion of Access to Information Act 2 of 2000 and the Promotion of Administrative Justice Act 3 of 2000.63 The report also claimed to have reached more than two million readers through supplements placed in all national newspapers. ${ }^{64}$ Finally, the report mentioned that educational programmes had been flighted on air using the Justice Airwaves, Khaya Legal Talk and Law on Call radio programmes, which reached over three million listeners across the country. ${ }^{65} \mathrm{~A}$ ministry spokesman also stated in July 2009 that 'a number of awareness campaigns' were 'being carried out'. 66 If one assumes that the two aforementioned awareness campaigns reached different groups of people, approximately 5 million people were reached in total. Alternatively, at least 3 million people were made aware of the Act if one assumes that both awareness campaigns reached the same people. Therefore, it was not possible to determine the exact amount of people that had been made aware of the Act itself, but whether this was the case or not, one is inclined to say that 447 complaints in the financial year $2008 / 2009$ is indicative of a public awareness campaign that had been ineffective.

This ineffectiveness is also evident from what we were told by some courts during the 2009 survey. In George, information sessions held with people and non-governmental organisations (NGOs) in the community did not lead to an increase in complaints with only one case being reported during both the 2005 and 2009 surveys. The court personnel at the Worcester equality court had also distributed pamphlets although this did not result in an increase in the number of complaints. At the Zwelitsha equality court no complaints had been received despite the community having been made aware of the Act through various launches that were held. Efforts by court officials at various other courts also proved to be unsuccessful. At Germiston and

61 Kok 53. The clerk at the Kenhardt Equality Court also stated during the 2009 survey that the Court needed to hold outreach programmes more regularly to increase the number of complaints received.

62 Department of Justice Annual Report 2008/2009, Part 2: Programme Performance 8 (Annual Report).

63 As above. These Acts are mentioned under the heading 'Develop and promote the Constitution'.

64 Pretoria News, The Star, Daily News, Cape Argus, Daily Sun and Sowetan are mentioned here.

65 Annual Report (n 71) 8-9.

66 C Mboyisa 'Equality courts will stay' The Citizen 13 July 2009. The equality court clerk at Kwa-Mhlanga in Mpumalanga also indicated that an equality court indaba was due to take place on 28 October 2009 where they would discuss why the court had received no complaints. This indicates that at least some attempt was being made to ensure that the equality courts are effective. 
Randburg ${ }^{67}$ pamphlets were handed out about the equality court at the court premises. Officials from the Verulam equality court distributed pamphlets about the equality court to and made them available at local police stations, attorneys' offices and legal aid offices. Information from one of the equality courts was conflicting as we were told that a number of outreach programmes had been held, but also that not much advertising had been done as it would lead to people abusing the equality courts. All the courts listed above saw either no increase or a very small increase in the number of complaints received. Only the equality court in Eerstehoek saw an increase in the number of complaints received compared to other equality courts - 19 complaints had been received according to the 2009 survey compared to no complaints received when the 2005 survey was conducted. Based on this information, much more needed to be done to bring the equality court's existence and availability to the attention of the general public.

The vast majority of the courts that had received no complaints whatsoever were situated in small towns with a small population. The courts situated in larger centres had received a larger number of complaints, as is evident from the fact that the courts in Pretoria, Johannesburg, Middelburg and Durban had received the largest number of complaints in 2009. However, this is not the case in all major cities as the equality courts in Pietermaritzburg and Randburg had only received a few complaints each in 2009. This indicates that there seemed to be greater awareness of the Act among people who live in larger centres, but one does get the sense that people were generally not well informed and unaware of the Act and the equality court as a dispute resolution forum. The Department of Justice needs to do more to promote the Act and the equality courts. For instance, equality courts and what constitutes discrimination or hate speech in terms of the Act can be taught to high school students by incorporating it into the life orientation course of the high school curriculum. The existence of the equality courts and examples of discrimination and hate speech should be promoted at public meeting places such as taxi ranks, as this is a form of transport utilised by a large number of individuals in South Africa, especially poor and less affluent individuals who are envisaged to be the main beneficiaries of the Act.

\section{Conclusion}

Through the creation of equality courts, the Act ostensibly has a very important role in facilitating South Africa's transformation. ${ }^{68}$ The Act's

67 We were told by the equality clerk that the Department of Justice was slow to send him posters regarding the Act, which were to be used for marketing purposes.

68 Preamble of the Act. 
objectives as well as its constitutional origin ${ }^{69}$ mean that the remedies that the Act seeks to provide through the establishment of equality courts must be accessible to all. ${ }^{70}$

It is also of crucial importance for the equality courts to be easily accessible by the public and that the contact information provided to the public in the DOJ's Equality for all booklets and on its website is correct. In eight of the nine provinces we encountered a number of problems in contacting some of the courts during the 2009 survey due to incorrect contact information provided by the DOJ. The numbers for the Pietermaritzburg, Ladysmith, Upington, Nkomazi, Middelburg, Polokwane, Vryburg, Kempton Park, Pretoria, Port Elizabeth, Somerset West and Elliotdale equality courts were incorrect. In each instance we attempted to obtain the correct number from directory enquiries, but in the case of Port Elizabeth we were still unable to reach the equality court. The DOJ should have taken greater care to ensure that the numbers provided by it were correct in all these instances. At the end of 2009 the incorrect numbers provided for the first-phase equality courts remained on the DOJ's website. ${ }^{71}$

If government is to fulfil its commitment of making every effort to ensure that these courts are fully functional and continue to serve the public, $^{72}$ then correcting the mistakes such as the information provided would be a good starting point. The DOJ must also ensure that each equality court has an equality clerk appointed or designate a person to act as equality clerk, as it is bound by the Act to do so. ${ }^{73}$ Only when this happens and the public makes more frequent use of the equality courts to resolve issues dealing with equality, can we say that the courts are efficient and that the Act to some extent is achieving its purpose, which the 2005, 2009 and SAHRC surveys unfortunately showed was not the case.

Subsequent to the 2009 surveys, we approached the Durban, Johannesburg and Pretoria equality courts with a view to obtaining copies of the actual case files to do more in-depth empirical research. We were able to obtain 564 of the case files from the 594 complaints heard by the Durban equality court between 2003 and 2012, only 97 case files from the Pretoria equality court $^{74}$ pertaining to complaints heard between 2008 and 2012, and 186 case files of the 200 complaints heard by the Johannesburg equality court between 2004 and 2012. Unfortunately, this research study confirmed that equality courts, even those in these three large cities, were still not receiving a

69 The Act was enacted pursuant to sec 9(4) of the Constitution, which states that national legislation may be enacted to prevent or prohibit unfair discrimination.

70 See sec $4(1)(b)$ of the Act which states that 'access to justice to all persons in relevant judicial and other dispute resolution forums' is one of the guiding principles of the Act when proceedings are instituted.

71 http://www.doj.gov.za/EQCact/eqc_eqc\%20structures.htm (accessed 18 December 2009).

72 Preamble of the Act.

$73 \operatorname{Sec} 17(2)(b)$ of the Act. 
large number of complaints after 2009. The legislature should consider amending the Act so that the equality court can also hear labour-related discrimination disputes as it might lead to an increase in the number of complaints received. A large number of complaints received by anti-discrimination tribunals in other countries were employment-related. For example, a survey of cases heard by antidiscrimination tribunals in Canada between 1996 and 2003 showed that a vast majority of the 385 complaints received were employmentrelated. ${ }^{75}$ Finally, the Act should be translated into plain language or promotional material such as pamphlets should explain in very simple language what discrimination, hate speech and harassment are, unlike the current booklet on the Act in which the definitions of these terms are merely set out as they appear in the Act. ${ }^{76}$ We submit that these changes will contribute to the public making use of equality courts more extensively and will increase the effectiveness of the Act through the public's use of equality courts. That said, the regulations and sections of the Act dealing with the promotion of equality should be operationalised as soon as possible, as this arguably is the most significant reason why the Act has not had its envisaged impact.

74 According to the equality clerk many of the case files for complaints brought in 2009 and before then were destroyed in a fire during 2010. See http:// www.news24.com/SouthAfrica/News/Blaze-closes-Pretoria-Magistrates-Court-201 01027 (accessed 9 December 2014). However, the clerk could not give us the exact number of complaints received up to the end of 2012 and said that he also did not know where many of the case files were.

75 See Kok (n 10) 434-575.

76 http://www.justice.gov.za/EQCact/docs/2011 eqc-a5-booklet.pdf (accessed 9 December 2014). 